\title{
Influence of Local Revenue Management on Financial Distress in Selected County Governments, Kenya
}

\author{
John Muthini Ndunda ${ }^{1} \quad$ Prof. Willy Muturi ${ }^{2} \quad$ Dr. Daniel Wanyoike ${ }^{3}$ \\ 1.School of Business, Jomo Kenyatta University of Agriculture and Technology, P.o. Box, 1063, Nakuru, Kenya \\ 2.School of Business, Jomo Kenyatta University of Agriculture and Technology, P.o. Box, 6200, Nairobi, Kenya \\ 3.School of Entrepreneurship, Procurement and Management, Jomo Kenyatta University of Agriculture and \\ Technology, P.o. Box, 1063, Nakuru, Kenya
}

\begin{abstract}
The county governments of Kenya have recently encountered difficulties in settling their liability obligations to employees, suppliers, and creditors. Counties ought to act as economic and social transformational tools for the Country's residents, but this is not the case. County governments deliver services to the residents through their own revenue and equitable transfers from the national government. As such, revenue collection and utilization is a vital aspect of service delivery. However, County Governments have continuously failed to meet revenue targets, and some cannot account for the revenue expenditures. This explains their inability to settle the debt and other liabilities as they come due for payment. Therefore, it was necessary to examine the influence of local revenue management on financial distress in County Governments of Kenya. The study was further guided by wrecker's theory of financial distress. The study applied a descriptive survey design to obtain in-depth information from the auditors and accountants from Nairobi, Nakuru, Kakamega, Meru, and Kilifi County Governments. A stratified random sampling technique was applied to obtain a sample of 103 from 212 auditors and accountants. Structured questionnaires were used to collect data that was analysed through descriptive and inferential statistics with the aid of statistical packages for social sciences (SPSS). Study findings were presented by tables. Descriptive and inferential results indicated that revenue management influenced financial distress. The correlation coefficient $(\mathrm{R}=.613 ; \mathrm{p}=.000)$ indicated that the relationship between local revenue management and financial distress was positive and statistically significant.The beta coefficient $(\beta=.578 ; \mathrm{p}<0.01)$ was significant at $99 \%$ confidence level implying that local revenue management influenced financial distress in the county governments of Kenya.The research work will guide departments of finance in National and County Governments on how to effectively utilize financial resources, manage debts, and other liabilities. Corporate organizations will find it important in formulating strategies aimed at combating financial distress in their organizations.
\end{abstract}

Keywords: Local Revenue Management, Financial Distress, County Governments

DOI: $10.7176 /$ RJFA/11-12-05

Publication date:June 30th 2020

\section{Introduction}

Revenue management is a vital aspect of financial Management, not only in County or local governments but also in the National Governments (Turley, Robbins \& McNena, 2015). Revenue management guides Management of revenue resources, expenditures, and provision of essential services to the citizens at different levels in a Country. Financial Management establishes the standards, systems, and frameworks for effective Management of revenues and other financial resources for economic stability (Brown, 2017). The basis for the allocation of public funds and accounting for public expenditures and income indicates the financial management effectiveness in government entities. Overall, financial management in the government sector incorporates Management of revenue and expenditure framework of public funds (Hadi, Handajani, \& Putra, 2018). Local authorities worldwide encounter the common challenge of managing revenue and maintaining sufficient financial resources to fulfill the needs of the public. Moreover, sometimes, they are unable to utilize these revenues to settle bills owed to suppliers and debtors, thus contributing to financial distress among County Governments (Njeru, 2016).

Financial distress among local authorities has an enormous economic consequence that results in failure and cripples service delivery to the people (Ntoiti, 2013). Therefore, the determination of financial distress in County governments is a matter of considerable interest to the national government, county employees, creditors, suppliers, investors, and residents. These stakeholders are concerned about the county government's financial health (Nderitu \& Jeremiah, 2018). Payments to the suppliers and service delivery to the people are not assured should the County governments struggle financially. Nderitu and Jeremiah (2018) asserted that prolonged financial distress could force the County Government into bankruptcy and transfer of responsibilities to the National government. County Governments under financial distress lose the confidence of potential investors, the public, and the supplies (Biwott, 2015). Financial distress is contributed by the inability of the organization or institution to earn revenues sufficient to cover its costs, exclusive of costs of financing, and such organization is said to have negative economic value. 


\subsection{Statement of the Problem}

County Governments in Kenya are tasked with bringing public services closer to the people under the devolved system of government in the Country (Cheruiyot, Namusonge, \& Sakwa, 2018). Appropriateness of County Governments' financial Management indicates their ability to deliver services effectively. Local revenue management is a key component of financial Management that drives the devolved functions. Therefore, collection and utilization revenues affect payments and settling of other liability obligations by County Governments. The pending bills by County governments have been on an upward trend since the year 2013 when devolution came into effect. According to the annual report of the year 2017 by Auditor general, County Governments had pending bills of Kshs. 35.8 billion for the financial year 2016/2017. They collected revenue of Kshs. 32.2 billion and spent Kshs.319.015 billion. The national government had allocated them Kshs. 298.3 billion in the same period. County governments in Kenya are struggling with financial distress due to improper revenue management, which means revenue collected falls short of targeted amount. They have not been able to settle their liabilities, such as payment of salaries and debts owed to contractors and suppliers hence forced to operate on huge debts that attract higher interest rates due to failure to settle bank loans. For instance, Kilifi County collected Kshs.159 million against the target of Kshs. 766 million translating to the shortfall of Kshs. 607 million. Revenue collection and utilization plays a vital role in service delivery among County Governments. Flaws in local revenue management contribute to financial distress as well as unsustainability in County Governments. Therefore, the study examined the influence of revenue management on financial distress in the county governments of Kenya.

\subsection{Objective of the study}

The objective of the study was to examine the influence of local revenue management on financial distress in county governments of Kenya.

\subsection{Research Hypothesis}

$\mathbf{H}_{01}$ : Local revenue management does not significantly influence financial distress in county of Kenya.

\section{Literature Review}

\subsection{Theoretical Review}

The study was guided by wreckers theory of financial distress. This theory provided insight into local revenue management and financial distress among County Governments.

\section{Wreckers Theory of Financial Distress}

Wrecker's theory, as cited by Meeme (2015), has been applied mainly in the field of finance by various organizations worldwide in an attempt to solve the problem of financial distress. The wreckers' theory seeks to explain the benefits that may step out of financial distress to stakeholders. In the context of county governments, the approach tries to describe how the counties can get themselves out of the failure to settle financial obligations and commence effective service delivery to the citizens (Wangige, 2016). A big part of the causes of financial distress is the local government's own making concerning revenue resources. They fail to manage revenue in terms of collection and utilization. If appropriate measures guiding the same are formulated and strictly implemented, institutions will achieve optimization in the collection and avoid wastages in the usage of revenue; hence financial difficulties which lead to distress will have significantly decreased (Ng'eni, 2016). The performance of financially distressed institutions in the capital markets is low than that of financially stable organizations (Hummel, 2015). This is usually motivated by the desire among investors to opt-out before the firm ultimately fails, and they lose their investment. The act of withdrawing funds from already financially distressed companies who, on the contrary, desperately need those funds means wrecking (Boex \& muga, 2009). This action can also be explained as the process of pre-emptive destruction of a company before its value ultimately plummets to a value beyond salvage. Investors withdraw resources from the firm as private, non-dividend benefits. In the case of local/county governments, agencies of goodwill might remove their support in many projects needed by the people when they observe that public funds are mishandled by the management (Scoemann, 2011). Financially distressed company's shareholders will only suffer opportunity cost if the company recovers, however, if it defaults on its obligations, the withdrawal of funds is deemed a free source of funds which can be reinvested somewhere else for an acceptable return. This act is compared to the traditional concept of ripping apart an old ship, which is beyond or too expensive to repair and utilizing its parts to put another newer one (Scoemann, 2011). When predicting failure over long horizons, the most critical and persistent firm characteristics that should be taken into account include; market capitalization, market to book ratio, and equity volatility. Financially distressed firms have traditionally delivered anomalously low returns. This creates a safe environment for predator firms such as private equity funds to swoop in and acquire control and chart a new course for the firm through corporate restructuring. Wrecker's theory was useful in explaining the revenue management and other financial challenges facing county governments and how they can develop strategies to minimize them and increase public trust. Moreover, it assisted in explaining the 
influence of the revenue management dimension of financial management on financial distress and how it could be mitigated.

\subsection{Conceptual Framework}

The conceptual framework outlines the presumed association between the independent variableand dependent variable. Figure 2.1 illustrates the relationship between local revenue management and financial distress.



\section{Independent Variable}

\section{Dependent Variable}

\section{Figure 2.1: Conceptual Framework}

\subsection{Local Revenue Management}

Financial distress in local governments from most developing countries is influenced by the revenue management applied by the government administrations (Maina, 2013). Lack of sound revenue billing and invoicing contributes to inadequate collection destabilizing the financial positions of County/local Governments. Nuluva (2015) opined that the central government's inept policies and fiscal regulations concerning revenue collection and utilization by local governments hindered them from undertaking their mandate as required by the people. Therefore, ineffective revenue structures affected their capacity to carry out their obligations. Furthermore, there are inadequate advanced processes and systems in place to curtail fraud and compliance in revenue mobilization from developing countries. Revenue collection frequently is about government agency billing the public or a member of the public for taxes, fines, or any other charges (Nuluva, 2015). It also entails the comprehensive collection of revenue for debts owed or owed revenue by persons or businesses to the local government, thus mean collecting outstanding financial obligations from the public. Those financial obligations can come in a variety of sources; taxes, license fees, fines, or use of state facilities. Insufficient revenue leads to financial distress and is influenced by a lack of funds and information. Lack of funds or insufficient to repay a debt is often an obstacle in revenue collection, while a lack of information to the taxpayer contributes inadequate local revenue. Local governments fail to achieve optimal revenue due to little details on the existing business entities (Gituma, 2017). As a result, it became challenging to mobilize revenue and attain sustainable levels. Moreover, the current integrated revenue payer information systems did not help resolve loopholes in the revenue payment.

Poor revenue decisions are a result of incompetent officers in county governments (Gituma, 2017). This means that the money collected did not have a substantive impact on the residents. The local governments' top management is required to make informed decisions in order to optimize the economic well-being of the people, but this is yet to be observed, particularly in developing countries. Ndunda, Wanyoike, and Ngahu (2015) opined that little effort had been put to ensure that revenue collectors have the key competencies that could lead to revenue optimization in county governments. Furthermore, organizations need strategic tools to track their revenues and ensure that they are on an upward trend and in line with the changing economic conditions. However, local governments are devoid of these instruments hence cannot detect uncouth actions leading to inadequate funds, which contribute to financial distress. Revenue is utilized inappropriately in many cases by the local governments through the adoption of short-term views regarding budgets. This consumed the funds that were meant for long term service delivery to the people leading to their reluctance to paying taxes as required by the law. Management of local government is likely to fail when they don't initiate the expansion of their bookkeeping in revenue activities to include advanced accounting techniques (Dollery, 2012). Furthermore, effective bookkeeping was found to be an essential tool that enhanced the recording of revenue activities and accounting activities. This assists in projections and analysis of revenue utilization. Appropriate budgets assist organizations in projecting revenues collection and use (Ekwubi, 2010).

According to Turley, Robbins \& McNena, (2015), the local government's top management have to lay emphasis on the revenue collection and ensure that all sources are exhausted. The revenue collection and spending and accounting are closely related functions in local governments. Larkey (2015) also suggested that the government's solvency should be maintained by planning the revenue collection and utilization to satisfy its obligations by spending where it matters. Boetti, Piacenza, and Turati (2012) opined that Local revenues need to be adequate to meet the cost of the services and infrastructure they are intended to finance. They should also be 
buoyancy; that is, the overall revenues should change roughly in proportional to the economic base. The tax base should grow automatically when prices rise, the population grows, or the economy expands to meet expanding demands for service delivery (Fjeldstad \& Heggstad, 2012). Revenue collections need to be stable and predictable to facilitate planning and budgeting while at the same time collection and administration costs need to be minimized. Local revenue autonomy and flexibility need to be reinforced, and tax instruments need to be politically acceptable.

A sound revenue management framework for local governments is crucial for the success of devolution in the Country (Boetti et al., 2012). Additionally, local revenue mobilization enhances political and administrative accountability by empowering local residents. Generally, Counties have two categories of revenue; County owns revenue and central government transfers. Central or national government transfers consist of grants and revenue sharing. The stabilization objective of a Country's fiscal system requires central government control over the revenue instruments that may substantially influence budget deficits (Fjeldstad \& Heggstad, 2012). In many developing countries, local governments seem to raise whatever taxes, fees, and charges they are capable of raising, often without worrying excessively about the economic distortions and distribution effects that these instruments may create.

A complicated and non-transparent local government revenue system is costly to administer, and it facilitates corruption and mismanagement (Boetti et al., 2012). Furthermore, many local revenues have a distorting effect on resource allocation decisions that impact on economic growth. Such facts emerge when there is a significant deviation or disparity of the revenues sought by the Country government the nature of the trade undertaken by the residents. In some cases, trade license fees may be too high for the small scale businesses to afford and survive. Multiple licenses can also result in the tax burden falling more on the poor than on the relatively better off in residents. This is mainly due to the management of the local revenue in terms of collections and utilization. Generally, a keen focus on revenue management should emphasize on the cost-effectiveness of revenue collection, taking into account not only the direct costs of revenue administration but also the overall costs to the economy, including the compliance costs to local enterprises. Revenue management ought to minimize losses through the reduction of corruption among the revenue collectors.

\subsection{Empirical Review and Research Gaps}

Past related studies were reviewed with the aim of identifying relevant research gaps. A study by Odoyo, Moses, John, Aila, Ojera, and Siringi (2013) sought to establish the relationship between revenue collection and information systems by Local Authorities. They found that regular auditing complements reasonable efforts towards effective financial management in organizations. Therefore, the audit is more or less a practice which may be called a technique for ensuring a more effective internal check on financial management in county governments. The research did not discuss essential revenue management practices, such as collection and allocation mechanisms. Moreover, revenue collection strategies were not linked to financial distress.

Cheruiyot, Namusonge, and Sakwa (2018) did a study on the effect of financial planning and budgeting practices on the performance of county governments in Kenya. The study aimed at contributing new dimensions in policy formulation in the management of public resources and service delivery. The study found out that while various counties utilize County Integrated Development Plan as its primary planning document for all the projects and programs, timely disbursement and resource allocation have always remained the principal means of implementing them. This study did not clearly explain the role of revenue management in combating financial distress among County Governments.

Gitaru (2017) did a study on the impact of system automation on revenue collection in Kenya Revenue Authority using a Case of SIMBA. The results established that the revenue collected was directly proportional to the exchange rates due to the positive sign in the coefficient. In conducting an analysis of variance in the Gretl software, the probability value of p-value $2.6 \mathrm{e}-013$ was obtained, showing that the regression model was significant in predicting the relationship all the coefficients and revenue collected at a $95 \%$ level of significance. The study findings also established that there was a considerable increase in the revenue collected after the automation of the Simba system. The Exchange rates had an inverse effect on the revenue collected after the automation to the Simba system. The study was about revenue collection by the national government and not county governments. It did not, therefore, describe financial distress in line with revenue management.

A research study by Owino, Senaji, Eng, and Ntara (2017) examined the effect of innovation in revenue collection processes on the organizational performance of Nairobi City County. Content analysis was used for the qualitative data and then presented in prose. The study also conducted a multiple regression analysis to establish the relationship between the variables. The study found that the online billing process had a very great extent on organizational performance. The study deduced that the online receipting process significantly affects organizational performance in Nairobi County. The research further established that online receipting makes electronic communication between two parties more comfortable compared to physical receipting. The implications of revenue collection processes on service delivery were not expressed well. Furthermore, the 
settlement of liability obligations by the County Government of Nairobi was not analyzed in the research study.

A research study by Mugambi and Wanjohi (2018) on the factors affecting the implementation of revenue collection systems in county governments in Kenya found that ability to make payments using mobile money Platforms and tax payer's ability to pay rates, fees through different bank accounts were outstanding. The study further found out that revenue collection systems used have achieved expected revenue targets, and revenue collection systems available have improved taxpayers' compliance to a greater extent. The study found out that the respondents strongly agreed that they are encouraged to take responsibility for their personal development, learning, and career growth. Besides, the study found out that respondents agreed that they had been trained on revenue collection systems available in the last year and that employee experience, knowledge, skills \& competence will improve service delivery. Taxes payable to County Governments should be distinct from the ones payable to the National Government. The preceding would reduce tax evasion, non-compliance, and also Double Taxation of Citizens. All variables were significant since their p-values were less than 0.05.

Ntoiti (2013) carried out a study on the determinants of Financial Distress Facing Local Authorities in Service Delivery in Kenya. It was guided by financial management practices, human resource management practices, corporate governance practices, information technology, and government regulation constructs. Findings indicated that all these variables had a negative and significant relationship with financial distress. Therefore, financial distress in local authorities would have decreased with their increased effectiveness. This hence implied that improved effectiveness of financial management practices, human resource management practices, corporate governance practices, information technology, and government regulation would lead to decreased financial distress in local authorities. The study was conducted from the defunct municipal and county councils. Changes evidenced in the County set-ups were not considered during that time.

\section{Research Methodology \\ 3.1 Research Design}

Research design is the framework under which the study is undertaken. As argued by Smith (2015), the research design is an arrangement of conditions for collection and analysis of data in a manner that aims to combine relevance with purpose. Research design can be considered as the structure of research that holds all of the elements in a research project together (Lakshmi \& Mohideen, 2013). This study adopted a descriptive survey design to come up with sufficient and relevant information for the research. A descriptive research design is concerned with gathering information about prevailing conditions for description and interpretation. It helped to explain and facilitate the critical evaluation of county governments of Kenya regarding local revenue management and financial distress.

\subsection{Target Population}

Population refers to the aggregate number of people or individuals with similar features or characteristics. According to Rea and Parker (2014), the population is any group of individuals who have one or more attributes in common that are of interest to the researcher. The target population of the study is the population from which respondents are drawn, data collected from them, and study findings are generalized. This study was intended for the county governments of Kenya with special reference to financial difficulties that had been observed in them. Five selected county governments with a population of above one in 2009 census million people participated in the study. They include; Nairobi, Nakuru, Kakamega, Meru, and Kilifi Counties. The researcher targeted all the 212 accountants and auditors from ministries and sub-counties in the five selected County governments of Kenya. These people are engaged in financial activities of the organization, thus deemed capable of giving insights into the problems that they are facing in their work in relation to financial distress. In a bid to provide a solution, the researcher expected and obtained sufficient information from the respondents.

\subsection{Sample Size and Sampling Technique}

According to Draugalis and Plaza (2009) the sample refers to a group chosen from a larger population with the aim of yielding information about the population as a whole. It is a miniature picture of the entire group or aggregate from which it has been taken. According to Tonidandel \& LeBreton (2011) sampling is the process of selecting a sample of the respondents for the study in such a way that the individuals selected to represent the population from which they were selected. Proportionate stratified random sampling technique was applied by the researcher to obtain a sample of 103; 50 from ministries strata and 53 from sub-counties strata respectively. Sample size was determined through Nasiuma's formula (2000). The population was divided into two strata; the respondents from the ministries who are 100 in number and 112 from the sub-counties. The sample size was calculated from each stratum and then added together to comprise the total sample for the study.

The sample size was obtained as follows:

$$
\mathrm{NC}^{2}
$$$$
\mathrm{n}=
$$ 
Whereby;

$$
\mathrm{C}^{2}+(\mathrm{N}-1) \mathrm{e}^{2}
$$

$\mathrm{n}=$ Sample size

$\mathrm{N}=$ Population size

$\mathrm{C}=$ Coefficient of variation which is $50 \%$

$\mathrm{e}=$ Error margin which is 0.05

Substituting the values in the equation, the estimated sample size (n) was:

Sample size for accountants and auditors in sub-counties

$$
112(0.5)^{2}
$$

$\mathrm{n}=$

$$
0.5^{2}+(112-1) 0.05^{2}
$$

$\mathrm{n}=53.080 \quad \mathrm{n}=53$ respondents

Sample size for accountants and auditors in County government ministries $100(0.5)^{2}$

$\mathrm{n}=\frac{100(0.5)}{0.5^{2}+(100-1) 0.05^{2}}$

$\mathrm{n}=50 \quad \mathrm{n}=50$ respondents

Total sample was; $53+50=103$ respondents

\subsection{Data Collection Instruments}

Data was collected from the accountants and auditors of 5 selected County Governments. Questionnaires provide an opportunity for the adoption of practical ways in data gathering. Descriptive surveys are quantitative; thus, questionnaires are suitable for easy analysis of results (Chatterjee \& Hadi, 2015). Therefore, the study used questionnaires to collect primary data from accountants and auditors in the selected County Governments of Kenya.

\subsection{Data Analysis and Presentation}

Data analysis refers to the process of breaking complex information into smaller elements that can be quickly clarified and understood (Chatterjee \& Hadi, 2015). Therefore, data collected from the accountants and auditors were sorted, edited, coded, and analysed by descriptive and inferential statistics. The descriptive analysis incorporated measures of central tendency, means, and measures of variation such as standard deviations to describe how revenue management leads to financial distress in county governments of Kenya. The study furthermore adopted inferential analysis applying Pearson correlation and regression analysis. Pearson correlation coefficient measures the extent to which two variables tend to change together. It helped to explain the strength and the direction of the relationship between the variables under the study. The regression model is efficient, thus displaying findings in a detailed and advanced manner to establish the association between independent and the dependent variables (Mark, Philip \& Adrian, 2015). The analysis was executed with the aid of Statistical packages for social sciences (SPSS). The findings and discussions from the research were presented by statistical tables.

The following regression model was applied;

$\mathrm{Y}=\beta_{0}+\beta_{1} \mathrm{X}_{1}+\varepsilon$

Whereby;

$\mathrm{Y}=$ Financial Distress

$\beta_{0}=$ Constant (Coefficient of intercept of $\beta_{0}$ )

$\mathrm{X}_{1}=$ Local Revenue Management

$\varepsilon=$ Error of Margin

\section{Findings and Discussions}

\subsection{Descriptive Findings for Local Revenue Management and Financial Distress}

The researcher sought views and opinions of the respondents to establish whether local revenue management contributed to financial distress in County governments of Kenya. The results are presented on Table 4.1 in terms of percentages, mean and standard deviation. 
Table 4.1: Influence of Local Revenue Management on Financial Distress

\begin{tabular}{|c|c|c|c|c|c|c|c|c|}
\hline \multirow[t]{2}{*}{ Statement } & \multirow[t]{2}{*}{ n } & \multirow{2}{*}{$\begin{array}{l}\text { SA } \\
5\end{array}$} & \multirow{2}{*}{$\begin{array}{l}\mathbf{A} \\
4\end{array}$} & \multirow{2}{*}{$\mathbf{N}$} & \multirow{2}{*}{ D } & \multirow{2}{*}{$\begin{array}{l}\text { SD } \\
1\end{array}$} & \multirow[t]{2}{*}{ Mean } & \multirow[t]{2}{*}{$\begin{array}{l}\text { Std. } \\
\text { Dev }\end{array}$} \\
\hline & & & & & & & & \\
\hline $\begin{array}{l}\text { 1. Revenue management has a direct link to } \\
\text { ability of county governments to settle } \\
\text { financial obligations }\end{array}$ & 99 & $35.4 \%$ & $47.4 \%$ & $16.2 \%$ & $1 \%$ & - & 4.08 & .765 \\
\hline $\begin{array}{l}\text { 2. Appropriate revenue collection } \\
\text { strategies strengthens financial position } \\
\text { hence affects financial distress in County } \\
\text { Governments. }\end{array}$ & 99 & $32.3 \%$ & $43.4 \%$ & $22.3 \%$ & $1 \%$ & $1 \%$ & 4.05 & .825 \\
\hline $\begin{array}{l}\text { 3. Lack of capacity among revenue } \\
\text { collectors leads to insufficient collection. }\end{array}$ & 99 & $24.2 \%$ & $55.6 \%$ & $17.2 \%$ & $3 \%$ & - & 4.01 & .735 \\
\hline $\begin{array}{l}\text { 4. Allocation and utilization of collected } \\
\text { money affects the willingness of taxpayers } \\
\text { to pay revenue to county governments. }\end{array}$ & 99 & $5.1 \%$ & $25.2 \%$ & $39.4 \%$ & $25.2 \%$ & $5.1 \%$ & 3.00 & .958 \\
\hline $\begin{array}{l}\text { 5. Revenue payments mobilization } \\
\text { initiatives influence financial stability. }\end{array}$ & 99 & $3 \%$ & $35.4 \%$ & $31.3 \%$ & $21.2 \%$ & $9.1 \%$ & 3.02 & 1.030 \\
\hline $\begin{array}{l}\text { 6. Level of accuracy in revenue billing and } \\
\text { invoicing contributes to financial distress. }\end{array}$ & 99 & $37.4 \%$ & $41.4 \%$ & $19.2 \%$ & $2 \%$ & - & 4.14 & .796 \\
\hline $\begin{array}{l}\text { 7. Lack of proper fraud and leakage } \\
\text { management in revenue leads to financial } \\
\text { distress. }\end{array}$ & 99 & $30.3 \%$ & $52.6 \%$ & $13.1 \%$ & $3 \%$ & $1 \%$ & 4.08 & .804 \\
\hline
\end{tabular}

Findings indicate that the ability of County Governments to settle to their financial obligations is partly linked to the nature of revenue management. This was strongly agreed by $35.4 \%$ and admitted by $47.4 \%$ of the accountants and auditors in both ministries and sub-counties. The overall mean of the responses was 4.08 , with a standard deviation of $0.765 .75 .7 \%$ of the respondents at least concurred (mean=4.05; std. dev $=0.825)$ that appropriate revenue collection strategies strengthen are instrumental in determining financial position, thus affects financial distress in County Governments of Kenya. This meant that county governments are yet to establish the right revenue collection strategies and implement them. $24.2 \%$ strongly agreed while $55.6 \%$ admitted (mean $=4.01$; std. $\mathrm{dev}=0.735$ ) that insufficient revenue collection was contributed by lack of capacity among the collectors. $39.4 \%$ of respondents were indifferent (mean $=3.00$; std. $\mathrm{dev}=0.958$ ) that the taxpayers' willingness to pay revenue was somehow pegged on the way county governments utilizes public money. It was not apparent whether county residents paid revenue based on prudential use of the previously collected revenue. $31.3 \%$ of the respondents had differing opinions (mean=3.02; std. $\mathrm{dev}=1.030$ ) that revenue payment mobilization initiatives could affect the financial stability of the county governments. It was unclear whether there existed appropriate revenue payment mobilization initiatives, and their effect on financial distress could not be directly established. As such, the financial distress may or may not have been a result of a lack of revenue mobilization initiates in place. Respondents revealed (mean=4.14; std. $d e v=0.496$ ) that billing and invoicing ways influenced revenue management and that inability to manage leakages and fraud in revenue collection and utilization was detrimental to efforts towards coping with the problem of financial distress. Based on the above findings, it has been shown that revenue management is a key determinant of financial distress. The financial health of county governments mainly depends on revenue collection and utilization. The financial distress comes into place when the two actions are not undertaken appropriately, as indicated in the research findings.

\subsection{Correlation between Local Revenue Management and Financial Distress}

In order to find out whether local revenue management influenced financial distress in county governments of Kenya, the research carried the correlation analysis between the two. The results are presented on statistical Table 4.2. 
Table 4.2: Correlation between Local Revenue Management and Financial Distress

\begin{tabular}{llr}
\hline & & Financial Distress \\
\hline \multirow{3}{*}{ Revenue Management } & Pearson Correlation & $.613^{* *}$ \\
& Sig. (2-tailed) & .000 \\
& $\mathrm{~N}$ & 99 \\
\hline
\end{tabular}

**. Correlation is significant at the 0.01 level (2-tailed).

Based on the research findings, the relationship between revenue management and financial distress was strong, positive and statistically significant $(\mathrm{r}=0.613, \mathrm{p}<0.01)$ at $99 \%$ confidence level. This implies inability to collect enough revenue and mismanagement of available revenue by county governments of Kenya led to financial distress. Lack of visible development projects may have discouraged some traders from paying taxes to Counties and loopholes in collection meant that they lost a lot of taxes.

\subsection{Regression Analysis for Local Revenue Management and Financial Distress}

The study sought to establish the relationship between revenue management and financial distress among county governments of Kenya. Regression analysis was performed and results are illustrated on Tables 4.3, 4.4, and 4.5. Table 4.3: Model Summary for Revenue Management and Financial Distress

\begin{tabular}{lcccc}
\hline Model & R & R Square & Adjusted R Square & $\begin{array}{c}\text { Std. Error of the } \\
\text { Estimate }\end{array}$ \\
\hline 1 & $.613^{\mathrm{a}}$ & .376 & .370 & .32711
\end{tabular}

a. Predictors: (Constant), Revenue Management

The regression model summary indicates that correlation coefficient was $\mathrm{R}=.613$ thus financial distresses were influenced by revenue management. The coefficient of determination was $\mathrm{R}^{2}=.376$ implying that $37.6 \%$ variation in financial distress was caused by variation in revenue management among County Governments of Kenya.

Table 4.4: ANOVA ${ }^{\text {a }}$ for Local Revenue Management and Financial Distress

\begin{tabular}{|c|c|c|c|c|c|}
\hline Model & Sum of Squares & df & Mean Square & $\mathbf{F}$ & Sig. \\
\hline Regression & 6.260 & 1 & 6.260 & 58.503 & $.000^{\mathrm{b}}$ \\
\hline 1 Residual & 10.379 & 97 & .107 & & \\
\hline Total & 16.639 & 98 & & & \\
\hline
\end{tabular}

a. Dependent Variable: Financial Distress

b. Predictors: (Constant), Revenue Management

Regression findings, Analysis of Variance (ANOVA) results in particular indicated that the F-value=58.503. The model was fit for the data and revenue management determined financial distress in County Governments of Kenya.

Table 4.5: Regression Coefficients ${ }^{\text {a }}$ for Local Revenue Management and Financial Distress

\begin{tabular}{|c|c|c|c|c|c|}
\hline \multirow[t]{2}{*}{ Model } & \multicolumn{2}{|c|}{ Unstandardized Coefficients } & \multirow{2}{*}{$\begin{array}{c}\text { Standardized Coefficients } \\
\text { Beta }\end{array}$} & \multirow[t]{2}{*}{$\mathbf{t}$} & \multirow[t]{2}{*}{ Sig } \\
\hline & B & Std. Error & & & \\
\hline (Constant) & 1.980 & .288 & & 6.874 & .000 \\
\hline I Revenue Management & .578 & .076 & .613 & 7.649 & .000 \\
\hline
\end{tabular}

a. Dependent Variable: Financial Distress

Regression Model; $Y=\beta_{0}+\beta_{1} X_{1}+\varepsilon$ was applied. Regression coefficients show that revenue management had a beta coefficient of .578 and a t-value of 7.649. Based on these values, the association between revenue management and financial distress was statistically significant at a $99 \%$ confidence level. The sig. value portraying the relationship was .000 and less than 0.01 significance level. As such, local revenue management contributed to financial distress among County Governments of Kenya. The researcher wanted to examine the influence of revenue management on financial distress. This hypothesis was made. $\mathbf{H}_{01}$ : Revenue management does not significantly influence financial distress in the county governments of Kenya. The findings led to the rejection of null hypothesis. The $t$ value for local revenue management was 7.649 . The beta coefficient $(\beta=.578 ; p<0.01)$ was significant at a $1 \%$ significance level. It implies that local revenue management influenced financial distress in the county governments of Kenya.

\section{Summary of Findings}

Descriptive findings established that local revenue management influences the financial distress in the county governments of Kenya. It was admitted by the majority of auditors and accountants that revenue management was not desirable regarding collection and utilization. Lack of appropriate revenue management meant that revenue collection was not exhausted. The collected revenue amount was not fully used for the service delivery purpose, thus exposing county governments to financial distress. Respondents strongly agreed that the ability to settle financial obligations had a direct linkage to local revenue management. It was also revealed that county 
governments of Kenya lacked appropriate revenue collection strategies; thus, their financial position without transfer of funds from the national government lacked stability. Auditors and accountants further agreed that billing and invoicing ways influenced revenue management and that inability to manage leakages and fraud in revenue collection and utilization was detrimental to efforts towards coping with the problem of financial distress. However, the respondents had differing opinions with the argument that revenue mismanagement in terms of usage discouraged the business entities from continuing to pay revenue leading to unnecessary court battles that were a liability to county governments at some stages of operations. Correlation analysis revealed that there was a positive relationship between revenue management and financial distress. As such, the inability to collect enough revenue and to utilize it prudently contributed to financial distress in the county governments of Kenya. The regression analysis results led to rejection of null hypothesis since local revenue management contributed to financial distress.

\section{Conclusion}

Financial distress in the county governments of Kenya is caused by a lack of appropriate revenue collection strategies. It was revealed that county governments collected a relatively low amount of revenue concerning the transfers made by the national government. This means that without a proper strategy for collection, the counties have problems to settle their obligations as they come due. The way revenue has used the message to the taxpayers on whether it is to continue paying. Misuse of collected funds has left the business entities complaining about the behavior of county governments. The reluctance effect of this is a reluctance to further pay revenues, thus weakening the financial position of the county governments. Many counties are yet to identify and gazette all areas of revenue collection; hence mobilization is insufficient. Financial distress has also been influenced by the loss of revenue through deliberate wrong billings and invoicing that some collectors charge low contrary to what is provided for by the law. It has become challenging to manage revenue fraud and leakages. Some business entities operate without trade licenses as a result of collusion with county government officers. This denies county funds that they could have used to settle their obligations.

\section{References}

Biwott, E. K. (2015). Integrated financial management information systems implementation and its impact on public procurement Performance at national government of Kenya (Doctoral dissertation, University of Nairobi).

Boetti, L., Piacenza, M., \& Turati, G. (2012). Decentralization and local governments' performance: how does fiscal autonomy affect spending efficiency? Public Finance Analysis. 68(3), 269-302.

Boex, J., \& Muga, M. C. (2009). What Determines the Quality of Local Financial Management? The Case of Tanzania. Urban institute centre on international development and governance.

Brown, C. O. (2017). The politics of government financial management: Evidence from state bonds. Journal of Monetary Economics, 90, 158-175.

Cheruiyot, M. P., Namusonge, G. S., \& Sakwa, M. (2018). Effect of financial planning andBudgeting Practices on Performance of County Governments in Kenya. International Journal of Social Sciences and Information Technology.

Dollery, B., (2009). Financial sustainability in Australian local government: problems and solutions. Centre for Local Government, School of Business, Economics and Public Policy, University of New England

Draugalis, J. R., \& Plaza, C. M., (2009). Best practices for survey research reports revisited: implications of target population, probability sampling, and response rate. American journal of pharmaceutical education. 73(8), 142.

Ekwubi, C. (2010). The Problems of Effective Utilization of Revenue Available to Local Governments in Nigeria. A Case Study of Aninri Local Government Area of Enugu State.

Fjeldstad, O. H., \& Heggstad, K. (2012). Local government revenue mobilization in Anglophone Africa.

Gitaru, K. (2017). The Impact of System Automation on Revenue Collection in Kenya Revenue Authority. (A Case Study of SIMBA).

Gituma, H. K. (2017). Determinants of Effective Revenue Collection by Embu County, Kenya (Doctoral dissertation, University of Embu).

Lakshmi, S., \& Mohideen, M. A. (2013). Issues in Reliability and Validity of Research. International journal of management research and reviews, 3(4), 2752.

Larkey, P. D., (2015). Evaluating public programs: The impact of general revenue sharing on municipal government. Princeton University Press.

Maina, M. W. (2013). Factors Affecting Revenue Collection in Local Authorities in Kenya (A Case of Municipal Council of Nyeri) (Doctoral dissertation).

Mark, S. Philip, L.\& Adrian,T. (2009). Research methods for business students. $5^{\text {th }}$ ed. Pearson Education, England. Meeme, (2015). The relationship between adherence to BASEL III accord and financial distress status of 
commercial banks in Kenya (Doctoral dissertation, Doctoral dissertation, University of Nairobi).

Mugambi, F. K., \& Wanjohi, J. M. (2018). Factors affecting implementation of revenue collection systems in county governments in Kenya case of Meru County. International journal for research in business, management and accounting, 4(11), 525 .

Mugambi, K. W., \& Theuri, F. S. (2014). The challenges encountered by county governments in Kenya during budget preparation. IOSR Journal of Business and Management, 16(2), 128-134.

Nassiuma, D. K., (2000). Survey sampling: Theory and methods.

Nderitu, A. G., \& Jeremiah, K. (2018). Public sector accounting standards and financial reporting in central region County governments, Kenya (Doctoral dissertation, Kenyatta University).

Ndunda, J. Wanyoike, D. \& Ngahu. S, (2015). Analysis of factors influencing optimal revenue collection by county governments in Kenya: a case of Nakuru County. International journal of economics, commerce and management. 3(5): 1114-1129

Njeru, P. N. (2016). An assessment of integrated financial management information system implementation towards effective management practices in Nairobi and Lamu Counties (Doctoral dissertation, Strathmore University).

Ntoiti, J., (2013). Determinants of Financial Distress Facing Local Authorities in Service Delivery in Kenya (Doctoral dissertation).

Nuluva, D. B. (2015). Factors affecting revenue collection in local Government authorities: The case of four recognized local government Authorities in Morogoro region (Doctoral dissertation, Mzumbe University).

Odoyo, C. O., Moses, O., John, M. O., Aila, F. O., Ojera, P. B., \& Siringi, E. M. (2013). Effect of information systems on revenue collection by local authorities in Homa Bay County, Kenya. Universal Journal of Accounting and Finance, 1(1), 29-33.

Odoyo, F. S., Adero, P., \& Chumba, S. (2014). Integrated financial management information system and its effect on cash management in Eldoret West District Treasury, Kenya.

Rea, L. M., \& Parker, R. A. (2014). Designing and conducting survey research: A comprehensive guide. John Wiley \& Sons.

Schoeman, N. (2011). Fiscal Performance and Sustainability of Local Government in SouthAfrica. An Empirical Analysis and Working paper 201. South Africa.

Smith, H. J. M., \& Revell, K. D. (2016). Micro-incentives and municipal behavior: political decentralization and fiscal federalism in Argentina and Mexico. World Development, 77, 231-248.

Smith, J. A. (Ed.). (2015). Qualitative psychology: A practical guide to research methods. Sage.

Tonidandel, S., \& LeBreton, J. M., (2011). Relative importance analysis: A useful supplement to regression analysis. Journal of Business and Psychology, 26(1), 1-9.

Turley, G., Robbins, G., \& McNena, S. (2015). A framework to measure the financial performance of local governments. Local Government Studies, 41(3), 401-420.

Wangige, G. J. (2016). Effect of firm characteristics on financial distress of non-financial firms listed at Nairobi securities exchange, Kenya. Unpublished MBA Project. 